\title{
Reflections on ethical challenges associated with the Ebola epidemic
}

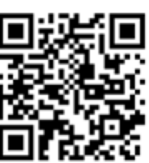

The recent tragic, horrifying and extensively reported Ebola epidemic ${ }^{[1]}$ must surely lead us to question why, despite major medical progress, such epidemics continue to emerge. We should also consider their implications for our global collective future. Seeking to understand the Ebola epidemic requires viewing it in the broadest historical and sociopolitical contexts that have shaped health globally, ${ }^{[2]}$ and specifically in West Africa. ${ }^{[3]}$

The West African context includes the 300-year slave trade from the 1500 s to the 1800 s, the scramble for Africa in the late 1880 s, the legacy of colonialism, and its more recent post-independence history characterised by weak governance, corrupt dictatorships, exploitative competition for its natural resources, conflict, serial wars and migration. As a result of these complex interacting forces and the region's vulnerability within the global political economy, West Africa is one of the world's poorest regions, with Liberia, Guinea and Sierra Leone being three of the world's poorest countries. In his controversial 1994 article 'The coming anarchy', Robert Kaplan ${ }^{[4]}$ wrote that 'West Africa is becoming a symbol of worldwide demographic, environmental and societal stress ... [its] conditions will soon confront our civilization ... West Africa's future, eventually will also be that of most of the rest of the world.' In the light of many recent world events, his predictions are evidently partly valid.

The first, most impressive and most sustained response to the recent Ebola epidemic predictably came from Médecins Sans Frontières (MSF), whose members yet again showed remarkable valour in taking on this major challenge ${ }^{[5]}$ (several South Africans volunteered to assist MSF in Sierra Leone $\left.{ }^{[6,7]}\right)$. The World Health Organization also made some contributions, but its response, like those of many others, was too little too late. ${ }^{[8,9]}$ President Obama's pledge to provide support at the end of October 2014 came just before the epidemic peaked. Eleven treatment centres were built by the USA when the epidemic was waning, so very few patients benefited.

Critics have viewed responses from those beyond Africa as being determined more by concerns for donor country security and fear of spread to their shores than concern for people whose lives had been blighted for many decades by, inter alia, global economic policies driven by neoliberal ideology. ${ }^{[2,3]}$ However, the more than USD4 billion contributed by many donors, combined with the dedicated efforts of local personnel, MSF and others, made it possible to control the epidemic ${ }^{[8]}$ The big question is whether a viable plan will be developed and implemented for future outbreaks.

The ethical challenges highlighted by the epidemic can be considered at three levels - interpersonal, public health and global.

\section{Interpersonal ethics}

Interpersonal professional ethics has been the topic of extensive debate over many decades, but some specific questions relevant to epidemics are unresolved. For example, it remains contentious whether it is ethical to use untested, unregistered, experimental treatments and interventions that have shown promising results in laboratory animal models, but may have unknown adverse effects in humans. It has been conceded by some that use of such treatments is justifiable, particularly for rapidly fatal diseases.

In reflecting on health professionals' duty to provide care, it is agreed that there are limits to such duties. What these limits are and how they may be determined involve complex considerations. Risks to life are inherent in many occupational roles, and dedication to helping others at great personal risk is a hallmark of striving for high professional ideals. Heroic efforts that go well beyond the call of duty are widely acclaimed, but cannot be expected as the norm. Notably, by 5 July 2015 there had been 875 cases of Ebola virus infection among medical staff in three West African countries, and 509 deaths.

\section{Public health ethics}

Academic discourse on public health ethics is maturing, but is not fully developed. ${ }^{[10]}$ Previously initiated debates continue on what trials of treatment should be undertaken, and under what conditions, in the context of epidemics. ${ }^{[1,12]}$ Prominence has also been given to the legitimate scope of quarantine measures to control outbreaks of infectious diseases and to how priorities should be set for treatment and prevention when resources are scarce. ${ }^{[11]}$ It is deeply troubling that global preparedness for public health emergencies is so inadequate and that preventive vaccines and effective therapies are not available when the cause of Ebola has been known since 1976 . Such shortcomings should sensitise us to how extreme poverty and lack of access to healthcare are tolerated until tragedies arise. ${ }^{[8,9]}$

These concerns are linked to distrust of national governments against the background of civil wars and brutality in these West African countries. Distrust extends to medical systems and external aid efforts that have responded poorly to much higher levels of morbidity and mortality from more common diseases (e.g. malaria, pneumonia) that are not perceived as very different from Ebola by local residents. Cultural considerations range from the impact of foreign assistance on local practices (for example burial rituals) to how participatory decision-making processes can be transparent in the complex context of pandemics. ${ }^{[8,13]}$

There is little new in recommendations for strengthening fragile healthcare systems, for improving national and international emergency preparedness, surveillance and monitoring, for strengthening community co-operation during emergencies, and for revising how new medical products are brought to market. Although previously addressed in relation to HIV, severe acute respiratory syndrome and H1N1 influenza, there has been little action of note. An incisive penetrating question is why more has not been learned from previous experience. ${ }^{[8]}$

\section{Global health ethics}

Ethical questions and deliberations at the global level are arguably the most critical and most disturbing ones to ask and address, as they concern power relations and macroeconomics. Who is responsible for widespread sustained poverty and adverse living conditions that allow new zoonotic diseases to emerge and spread? Why do we tolerate widening disparities in wealth that profoundly influence health and shape healthcare services? What ideological and institutionalised legalities drive the formation and continuation of deep, underlying structurally violent forces that have made the world a place that provides a good life for about $20 \%$ of people while the remainder struggle to live under highly adverse and unhealthy conditions? How is debt created and sustained? How should we evaluate global responses and global governance for health? Some of these ethical challenges have been addressed in the new and growing 
field of global health ethics, ${ }^{[2,10,14-19]}$ but with few exceptions ${ }^{[3,8,20]}$ have been neglected in the voluminous writings on the Ebola epidemic.

\section{Making progress}

Although the Ebola epidemic eventually came under control, avoidance of future epidemics should be informed by recognising Ebola not merely as a biomedical problem, but rather as a 'sign' of a serious, yet invisible, danger like the massive underwater component of an iceberg. Other danger signs, also with deep underlying forces (structural violence), contributing to reduced potential for good lives for many people, include recurrent global economic crises, wide disparities in health, dysfunctional and unsustainable healthcare systems, unpayable debt, ideological conflict, wars over access to resources, and the emergence of multidrug-resistant organisms. Environmental degradation and climate change consequent on excessive use of energy and massive pollution in a consumerist market civilisation are additional dangers. All these crises are fuelled by greed, corruption, flawed economic dogma and moral myopia. ${ }^{[1,17]}$

Will we do better in the future? In reviewing the past and speculating about the next 100 years, the philosopher John Gray ${ }^{[21]}$ has grimly suggested that '.. if geopolitics is the struggle of states for power over natural resources, we find ourselves in an era of geopolitical rivalry with cumulative adverse environmental effects ... the projects of international peace and world government that many cherished a century ago have not been realised and the pattern that is emerging at a global level looks likely to be another round in a remarkably familiar kind of human conflict.'

In asking what should be done, an analogy can be drawn with Kaposis sarcoma (KS) in patients with HIV/AIDS. Neither simple excision of KS tumours nor applying a 'balm' are effective. The development of effective life-extending treatment has flowed from research providing critical insights into the underlying systemic immune deficiency. Similarly, addressing the other abovementioned dangers to life, health and progress requires systemic critiques (from ecological, moral, social, political, economic and spiritual perspectives) of how we inhabit this planet, as well as transdisciplinary research and appropriate action. The goal should be to develop effective, rectifying systemic global responses that extend beyond provision of inadequate international aid. Improvements in global and planetary health require actions driven by more than individualistic, anthropocentric, international and biomedical conceptions of health, to include ecological and systems conceptions that acknowledge the complex interdependence of all life and the limits of our current approaches. ${ }^{[22]}$

Barriers to achieving meaningful global structural change include failure to admit that our predicament is in part attributable to the excessive entitlements and ways of life of privileged populations, and their belief that economic growth and ongoing scientific advances will provide all the solutions. Neglecting the deep underpinnings of all the above danger signs, with consequent perpetuation of severely adverse living conditions that foster poor health and continuing infectious disease pandemics, reflects our denial of the magnitude and multifactorial causality of multiple escalating global crises, and denial of the potential of human ingenuity to find solutions. ${ }^{[17]}$ Working towards sustainable global/planetary health is the major challenge of the 21 st century. ${ }^{[15,18,19]}$

\section{Solomon R Benatar}

Bioethics Centre, University of Cape Town, South Africa, and Joint Centre for Bioethics and Dalla Lana School of Public Health, University of Toronto, Canada

Correspondingauthor: S Benatar (solomon.benatar@uct.ac.za)

1. Times coverage of Ebola: Pulitzer winning articles and more. New York Times 2015; 20 April. http:// www.nytimes.com/interactive/2015/04/20/world/africa/ebola-coverage-pulitzer.html?_r=0 (accessed 12 October 2015).

2. Birn AE. Addressing the societal determinants of health: The key global health ethics imperative. In: Benatar S, Brock G, eds. Global Health and Global Health Ethics. Cambridge, UK: Cambridge University Press, 2011:37-52.

3. Sanders D, Sengupta A, Scott V. Ebola epidemic exposes the pathology of the global economic and political system. Int J Health Serv 2015;45(4):643-656. [http://dx.doi.org/10.1177/0020731415606554]

4. Kaplan RB. The Coming Anarchy. The Atlantic 1994; February. http://www.theatlantic.com/magazine/ Kaplan RB. The Coming Anarchy. The Atlantic 1994; February. http://www)
archive/1994/02/the-coming-anarchy/304670/ (accessed 12 October 2015)

archive/1994/02/the-coming-anarchy/304670/ (accessed 12 October 2015).
5. Ebola outbreak thrusts MSF into new roles: Relief agency sees its mission expanding after leading Ebola outbreak thrusts MSF into new roles: Relief agency sees its mission expanding after leading
response to West Africa epidemic. Nature News $2015 ; 3$ June. http://www.nature.com/news/ebolaresponse to West Africa epidemic. Nature News 2015; 3 June. http://wwwn
outbreak-thrusts-msf-into-new-roles-1.17690 (accessed 2 October 2015).

outbreak-thrusts-msf-into-new-roles-1.17690 (accessed 2 October 2015).
6. Burton R. Ebola: Experiences from the field - Liberia. S Afr Med J 1015;105(12):xxxx. [http://dx.doi. org/10.7196/SAMJ.2015.v105i12.10239]

7. Boyles T. Ebola: Personal view from the field - Sierra Leone. S Afr Med J 1015;105(12):xxxx. [http:// dx.doi.org/10.7196/SAMJ.2015.v105i12.9935]

8. Smith MJ, Upshur REG. Ebola and lessons learned from moral failures: Who cares about ethics? Public Health Ethics. Advance on-line publication 17 October 2015. [http://dx.doi.org/10.1093/phe/phv028] Garrett L. Ebola's lessons: How the WHO mishandled the crisis. Foreign Affairs 2015; 18 August. https:// www.foreignaffairs.com/articles/west-africa/2015-08-18/ebolas-lessons (accessed 12 October 2012).

10. Thompson A, Nixon SA, Upshur R, Robertson A, Benatar SR, Daar A. Public health ethics. In: Bailey TM, Caulfield T, Ries NM, eds. Public Health Law \& Policy in Canada. 3rd ed. Markham, Canada: Lexis Nexis Butterworths, 2013:37-57.

11. Donovan CK. Ebola, epidemics, and ethics - what we have learned. Philos Ethics Humanit Med 2014;9-15. [http://dx.doi.org/10.1186/1747-5341-9-15]

12. Ethics and Ebola: Public Health Planning and Response. Presidents Commission on Bioethics. February 2015. http://bioethics.gov/sites/default/files/Ethics-and-Ebola_PCSBI_508.pdf (accessed 12
Fond October 2015).

13. Komesaroff P, Kerridge I. Ebola, ethics and the question of culture. Bioeth Inq 2014;11(4):413-414. [http://dx.doi.org/10.1007/s11673-014-9581-9]

14. Benatar SR. Health in low-income countries. In: International Encyclopedia of the Social \& Behavioral Sciences. 2nd ed. Oxford: Pergamon, 2015:633-639.

15. Pogge T. World Poverty and Human Rights. Cambridge, UK: Polity Press, 2002.

6. Benatar SR. Global justice and health: Re-examining our values. Bioethics 2013;27(6):297-304. [http:// dx.doi.org/10.1111/bioe.12033]

17. Benatar SR, Gill S, Bakker I. Making progress in global health: The need for a new paradigm. Int Aff 2009;85(2):347-371.

18. Benatar S, Brock G, eds. Global Health and Global Health Ethics. Cambridge, UK: Cambridge University Press, 2011.

19. Pinto A, Birn A-E, Upshur R. The context of global health ethics. In: Pinto A, Upshur R, eds. An Introduction to Global Health Ethics. London: Routledge, 2013:3-15.

20. Benatar SR. Explaining and responding to the Ebola epidemic. Philos Ethics Humanit Med 2015;10:5. Benatar SR. Explaining and responding to the E
[http://dx.doi.org/10.1186/s13010-015-0027-8]

21. Gray J. What's going to happen in the next one hundred years. NewStatesman 2013; 15 May. http:// www.newstatesman.com/politics/2013/05/what-going-happen-next-hundred-years (accessed 12 October 2015).

22. Benatar SR. Health: Global. In: Ten Have H, ed. Encyclopedia of Global Bioethics. New York: Springer Living Reference Work, continuously updated online. [http://dx.doi.org/10.1007/978-3-319-055442_219-1].

S Afr Med J 2015;105(12):1012-1013. DOI:10.7196/SAMJ.2015.v105i12.10247 